\title{
Remediation of organic and inorganic arsenic contaminated groundwater using a nanocrystalline $\mathrm{TiO}_{2}$-based adsorbent
}

\author{
Chuanyong Jing ${ }^{\mathrm{a}, \mathrm{b}, *}$, Xiaoguang Meng ${ }^{\mathrm{b}}$, Edwin Calvache ${ }^{\mathrm{b}}$, Guibin Jiang ${ }^{\mathrm{a}}$ \\ a State Key Laboratory of Environmental Chemistry and Ecotoxicology, Research Center for Eco-Environmental Sciences, Chinese Academy of Sciences, 18 Shuangqing Road, \\ Beijing 100085, China \\ ${ }^{\mathrm{b}}$ Center for Environmental Systems, Stevens Institute of Technology, Hoboken, NJ 07030, USA \\ A nanocrystalline $\mathrm{TiO}_{2}$-based adsorbent could be used for the simultaneous removal of As(V), As(III), MMA, and DMA in \\ contaminated groundwater.
}

\section{A R T I C L E I N F O}

\section{Article history:}

Received 6 December 2008

Received in revised form

3 March 2009

Accepted 5 March 2009

\section{Keywords:}

Organic arsenic

Inorganic arsenic

Adsorptive filtration

$\mathrm{TiO}_{2}$

Charge distribution multi-site surface

complexation model

EXAFS

\begin{abstract}
A B S T R A C T
A nanocrystalline $\mathrm{TiO}_{2}$-based adsorbent was evaluated for the simultaneous removal of $\mathrm{As}(\mathrm{V}), \mathrm{As}(\mathrm{III})$ monomethylarsonic acid (MMA), and dimethylarsinic acid (DMA) in contaminated groundwater. Batch experimental results show that As adsorption followed pseudo-second order rate kinetics. The competitive adsorption was described with the charge distribution multi-site surface complexation model (CD-MUSIC). The groundwater containing an average of $329 \mu \mathrm{g} \mathrm{L}^{-1} \mathrm{As}(\mathrm{III}), 246 \mu \mathrm{g} \mathrm{L} \mathrm{L}^{-1} \mathrm{As}(\mathrm{V})$, $151 \mu \mathrm{g} \mathrm{L}^{-1} \mathrm{MMA}$, and $202 \mu \mathrm{g} \mathrm{L}^{-1}$ DMA was continuously passed through a $\mathrm{TiO}_{2}$ filter at an empty bed contact time of 6 min for 4 months. Approximately 11000,14000 , and 9900 bed volumes of water had been treated before the $\mathrm{As}(\mathrm{III}), \mathrm{As}(\mathrm{V})$, and MMA concentration in the effluent increased to $10 \mu \mathrm{g} \mathrm{L}^{-1}$. However, very little DMA was removed. The EXAFS results demonstrate the existence of a bidentate binuclear $\mathrm{As}(\mathrm{V})$ surface complex on spent adsorbent, indicating the oxidation of adsorbed $\mathrm{As}(\mathrm{III})$.
\end{abstract}

(c) 2009 Elsevier Ltd. All rights reserved.

\section{Introduction}

Arsenic is a naturally occurring metalloid and has caused great public concern because of its apparent carcinogenicity and detrimental health effects (Cullen and Reimer, 1989; Smedley and Kinniburgh, 2002). Inorganic arsenate $\mathrm{As}(\mathrm{V})$ and arsenite $\mathrm{As}(\mathrm{III})$, monomethylarsonic acid (MMA), and dimethylarsinic acid (DMA) are four arsenic species commonly found in the environment. In addition to naturally occurring As sources, anthropogenic sources, such as the manufacture and use of arsenical herbicides and insecticides, pose a potential threat to public health (Feng et al., 2005).

The U.S. remained the world's leading consumer of arsenic in 2006, mainly for the production of agricultural chemicals and wood preservatives (Brooks, 2006). Cumulative statistics indicate that between 1975 and 2003, inclusively, the U.S. has utilized 127860 and 391500 metric tons of arsenic for agriculture and wood

\footnotetext{
* Corresponding author at: State Key Laboratory of Environmental Chemistry and Ecotoxicology, Research Center for Eco-Environmental Sciences, Chinese Academy of Sciences, 18 Shuangqing Road, Beijing 100085, China. Tel./fax: +86 1062849523.

E-mail address: cyjing@rcees.ac.cn (C. Jing).
}

preservative purposes, respectively (USGS, 2005). As a result, soil and groundwater contamination occurs at multiple sites in the U.S. Currently, arsenic contamination has been found in 533 out of 1255 Superfund sites on the National Priorities List (http://www.epa.gov/ superfund/sites/query/basic.htm, accessed October 25, 2008). One of the Superfund sites in Southern New Jersey caused a 54-acre site As contamination by improper raw material storage and deposition of waste herbicide material in untreated piles and lagoons for over forty years (USAC, 1994). The groundwater is contaminated with inorganic and organic As with total concentration at the $\mathrm{mg} \mathrm{L}^{-1}$ level. A groundwater pump-and-treat remediation system has been under operation and is expected to last a few decades (USAC, 1994). A flow-through cartridge of Fe filings has been installed on site and could remove over $85 \%$ of the total As of which $30 \%$ was organic As (Cheng et al., 2005).

Among various technologies used for the removal of arsenic from water, adsorptive filtration has received increasing attention (USEPA, 2003; Mohan and Pittman, 2007). In recent years, commercially available adsorbents, including granular ferric hydroxide (GFH), granular ferric oxide (GFO), iron modified activated alumina, and hybrid anion exchanger (HAIX), have been widely used in As treatment. All media can treat tens of thousands of bed volumes of source water with low phosphate and silicate 
concentrations at neutral $\mathrm{pH}$. A side-by-side comparison of the media performed by the USEPA demonstrates that iron-based adsorbents (GFH, GFO) have the highest adsorptive capacity (mg As $\mathrm{g}^{-1}$ dry media) at $10 \mu \mathrm{g} \mathrm{L}^{-1}$ As effluent concentration (USEPA, 2008). However, the high As leachability in the spent GFH adsorbent may pose a potential threat to the environment (Jing et al., 2005a).

Recently, a nanocrystalline-based $\mathrm{TiO}_{2}$ adsorbent has been developed for effective removal of $\mathrm{As}(\mathrm{V})$ and $\mathrm{As}(\mathrm{III})$ (Pena et al., 2005,2006 ). The adsorbent has been used in a point-of-entry (POE) treatment for As removal from groundwater containing an average of $39 \mu \mathrm{g} \mathrm{L}^{-1}$ of $\mathrm{As}(\mathrm{V})$ (Bang et al., 2005). Approximately 45000 bed volumes of groundwater was treated by the POE filter before the effluent As concentration reached $10 \mu \mathrm{g} \mathrm{L}^{-1}$. Batch experimental results indicate that $\mathrm{TiO}_{2}$ has a moderate and low adsorption capacity for MMA and DMA, respectively (Jing et al., 2005b). However, with the addition of UV irradiation, $\mathrm{TiO}_{2}$ could photocatalytically mineralize MMA and DMA into $\mathrm{As}(\mathrm{V})$ and subsequently adsorb the converted $\mathrm{As}(\mathrm{V})$ (Xu et al., 2007, 2008). The mechanism of As adsorption onto $\mathrm{TiO}_{2}$ has been studied with extended X-ray absorption fine structure (EXAFS) spectroscopy (Jing et al., 2005a,b; Pena et al., 2006; Liu et al., 2008). Our previous EXAFS studies have shown that As adsorbs onto $\mathrm{TiO}_{2}$ through the formation of inner-sphere surface complexes with a bidentate configuration for $\mathrm{As}(\mathrm{V}), \mathrm{As}(\mathrm{III})$, and MMA, along with a monodentate structure for DMA (Jing et al., 2005a,b; Pena et al., 2006).

Most previous studies have focused on the removal of either inorganic or methylated As (Edwards, 1994; Thirunavukkarasu et al., 2002; USEPA, 2003; Mohan and Pittman, 2007). Although $\mathrm{TiO}_{2}$ has been successfully applied in groundwater $\mathrm{As}(\mathrm{V})$ removal, limited information is available for simultaneous remediation of four commonly found organic and inorganic As species in contaminated groundwater. The competitive adsorption of coexisting arsenic species has not been fully established. Therefore, the objective of this study is to evaluate the feasibility of using $\mathrm{TiO}_{2}$ adsorbent in As remediation for a groundwater simultaneously containing As(III), As(V), MMA, and DMA with a total As concentration in the $\mathrm{mg} \mathrm{L}^{-1}$ level. Batch experiments were performed to study the adsorption kinetics and the competitive adsorption. A one-dimensional advective transport model, coupled with kinetics and surface complexation reactions, was used to understand and simulate the adsorptive filtration process. The mechanism of As removal was investigated by EXAFS analysis.

\section{Materials and methods}

\subsection{Materials}

Stock solutions of arsenic were prepared by dissolving sodium arsenate heptahydrate $\left(\mathrm{Na}_{2} \mathrm{HAsO}_{4} \cdot 7 \mathrm{H}_{2} \mathrm{O}\right.$, Sigma Chemical, Minnesota, USA), sodium arsenite $\left(\mathrm{NaAsO}_{2}\right.$, Fisher Scientific, New Jersey, USA), cacodylic acid or dimethylarsinic acid $\left(\mathrm{C}_{2} \mathrm{H}_{7} \mathrm{AsO}_{2}\right.$, Sigma Chemical, Minnesota, USA), and monosodium acid methane arsonate sesquihydrate $\left(\mathrm{CH}_{4} \mathrm{AsNaO}_{3} \cdot 1.5 \mathrm{H}_{2} \mathrm{O}\right.$, Chem Service, Pennsylvania, USA) in distilled water. The nanocrystalline $\mathrm{TiO}_{2}$ was prepared by hydrolysis of titanium sulfate solution (Meng et al., 2005). The $\mathrm{TiO}_{2}$ produced was in the anatase form with an average crystalline particle size of $6 \mathrm{~nm}$. The Brunauer-Emmett-Teller (BET) specific surface area was $329 \mathrm{~m}^{2} \mathrm{~g}^{-1}$ and the surface hydroxyl site density was $6.0 \mathrm{mmol} \mathrm{g}^{-1}$. The point of zero charge of $\mathrm{TiO}_{2}$ was at pH 5.8 (Jing et al., 2005b). The granular $\mathrm{TiO}_{2}$ adsorbent with surface hydroxyl site density of $2.7 \mathrm{mmol} \mathrm{g}^{-1}$ was synthesized by agglomerating nanocrystalline anatase (Meng et al., 2005). The granulated $\mathrm{TiO}_{2}$ adsorbent with particle size between 30 and 60 U.S. standard mesh $(0.6-0.25 \mathrm{~mm})$ has a BET surface area of approximately $180 \mathrm{~m}^{2} \mathrm{~g}^{-1}$.

\subsection{Batch experiments}

Kinetic experiments were conducted to determine the adsorption rate of MMA and DMA on nanocrystalline $\mathrm{TiO}_{2}$. A 1 - $\mathrm{L}$ suspension containing $0.04 \mathrm{M} \mathrm{NaCl}$ $0.02 \mathrm{~g} \mathrm{~L}^{-1}$ of $\mathrm{TiO}_{2}$ and initial MMA or DMA concentration of $100 \mu \mathrm{g}$-As L ${ }^{-1}$ was prepared at the beginning of each experiment. The suspension was mixed in the dark with a magnetic stirrer, and the $\mathrm{pH}$ was maintained at 6.0 with $\mathrm{HCl}$ and $\mathrm{NaOH}$. At desired reaction times, uniform suspension samples were withdrawn from the beaker. The samples were filtered through a $0.4-\mu \mathrm{m}$ membrane filter for As speciation analysis using high-performance liquid chromatography coupled with atomic fluorescence system (HPLC-AFS). Separation of arsenic compounds was carried out in a Hamilton PRP-X100 anion exchange column, using $10 \mathrm{mM}$ phosphate buffer at pH 5.8 as mobile phase at $0.8 \mathrm{~mL} \mathrm{~min}^{-1}$ flow rate. Following the separation of As species, online hydride generation was achieved by reacting with $\mathrm{NaBH}_{4}$ and $\mathrm{HCl}$. The hydride was atomized in the hydrogen flame and the fluorescence signal for each of the As species was recorded using a PS Analytical 10.055 Millennium Excalibur (Kent, UK)

Batch adsorption experiments were conducted to study the competitive adsorption behavior of $\mathrm{As}(\mathrm{V}), \mathrm{As}(\mathrm{III}), \mathrm{MMA}$, and DMA simultaneously in groundwater on granular $\mathrm{TiO}_{2}$. The groundwater samples were purged with nitrogen and then transferred into $23100-\mathrm{mL}$ bottles. After varying amounts of granular $\mathrm{TiO}_{2}$ adsorbent were added to each bottle, they were covered with aluminum foil to prevent light exposure and oxidation. Then, the bottles were placed in a tumbler and mixed for $1 \mathrm{~h}$. The suspension $\mathrm{pH}$ was measured and adjusted to the raw groundwater value of 5.84 for those samples with a different $\mathrm{pH}$. After a total of $4 \mathrm{~h}$ mixing, the suspension was filtered through a $0.4-\mu \mathrm{m}$ membrane filter for soluble As speciation analysis.

\subsection{Field filtration experiments}

The adsorptive filtration experiments were conducted on the Vineland Chemical Superfund site over a period of 4 months from June to September. The $3.785 \mathrm{~L}$ (1 gallon) filter house, with an inside diameter of $11.4 \mathrm{~cm}$, was filled with $3 \mathrm{~L}(2178 \mathrm{~g})$ of granular $\mathrm{TiO}_{2}$ adsorbent. To prevent suspended solids flowing into the filter house, a sediment filter with a 5- $\mu$ m cartridge was installed in front of the $\mathrm{TiO}_{2}$ column. The flow rate was periodically monitored and controlled at $500 \mathrm{~mL} \mathrm{~min}^{-1}$, resulting in an empty bed contact time (EBCT) of $6 \mathrm{~min}$. Samples of raw water, pre$\mathrm{TiO}_{2}$ column (i.e., after sediment filter), and effluent were collected periodically and preserved with $5 \% \mathrm{HNO}_{3}$ on site. The As speciation analysis was performed within $4 \mathrm{~h}$ to avoid $\mathrm{As}(\mathrm{III})$ oxidation during sample storage time.

The $\mathrm{pH}$, redox potential, and dissolved oxygen (DO) were measured on site using a multi-parameter water quality monitoring system, Horiba U-22 (Horiba, JP). The concentrations of iron, manganese, and silicate were determined with Zeeman furnace atomic absorption spectrometry (AAS) and inductively coupled plasma (ICP) emission spectrometry. Phosphate concentration was measured using standard method 4500-P E (Clesceri et al., 1999) with a HACH DR/2010 spectrophotometer.

\subsection{Surface complexation and transport modeling}

A charge distribution multi-site complexation (CD-MUSIC) model with the triple plane option was used to describe the competitive As adsorption behaviors simultaneously. The basic principles of the model have been well documented in the literature (Hiemstra and van Riemsdijk, 1996, 1999). Constants for protonation of the surface hydroxyl groups and formation of outer-sphere complexes with background electrolytes were taken from our previous studies (Jing et al., 2005a,b) and listed in Table S1 in the Supplementary material. Only the singly coordinated surface group, $\mathrm{TiOH}^{-1 / 3}$, was responsible for the As adsorption in the CD-MUSIC modeling. The charge distribution (CD) value expressed the fraction $f$ of the charge of the central As ion attributed to the surface plane, and the remaining part $(1-f)$ was attributed to the other ligands of the complex, which were toward the diffuse layer (Jing et al., 2005b). The CD factor $f$ for a single As surface complex was obtained by modeling our previous published data of adsorption edge for each As species (Jing et al., 2005b; Pena et al., 2006) as shown in Fig. S1 in the Supplementary material. With the determined $\mathrm{CD}$ factor, the available surface site density and As surface complexation constants were optimized using batch experimental results to simulate competitive adsorption behaviors for all four As species simultaneously.

The adsorptive filtration studies were simulated using PHREEQC code version 2.15 and the MINTEQ database (Parkhurst and Appelo, 1999). The adsorption kinetics, CD-MUSIC model, as well as one-dimensional (1D) advective transport were included in the calculation. A 1D transport model column, comprising 10 cells with a length of $0.03 \mathrm{~m}$ each, was constructed to simulate the filtration with EBCT of $6 \mathrm{~min}$.

\subsection{EXAFS analysis}

At the end of the field filtration experiments, spent adsorbents at $5 \mathrm{~cm}$ depth below the surface and at $5 \mathrm{~cm}$ above the bottom were collected. The samples were placed in iced cooler and analyzed within $72 \mathrm{~h}$ after collection. The wet spent adsorbent samples were sealed between two layers of Kapton tape. The spectra were collected at cryogenic temperature $(70 \mathrm{~K})$ on beamline $\mathrm{X} 18 \mathrm{~B}$ at the National Synchrotron Light Source (NSLS) in the Brookhaven National Laboratory. An energy range of -200 to $1000 \mathrm{eV}$ from the K-edge of As $(11867 \mathrm{eV})$ was used to acquire the spectra. All spectra were collected in fluorescence mode using a 13-element energy dispersive Ge detector. About 4-6 scans were collected to achieve an adequate signal/noise ratio. Standard reference arsenic chemicals, $\mathrm{NaAsO}_{2}, \mathrm{Na}_{2} \mathrm{HAsO}_{4} \cdot 7 \mathrm{H}_{2} \mathrm{O}$, 
MMA and DMA, were also analyzed. Elemental arsenic $\left(\mathrm{As}^{0}\right)$ was used to calibrate the energy at $11867 \mathrm{eV}$.

The EXAFS spectra were analyzed with the Athena and Artemis program of the IFEFFIT computer package (Ravel and Newville, 2005). The standard EXAFS data process was followed as shown in our previous research (Jing et al., 2005a; Liu et al., 2008). Briefly, the spectra were processed by removing the background absorbance with a linear function through the pre-edge region, normalizing the atomic absorption, and extracting the EXAFS signal from the spectra. The spectra were converted to frequency $(k)$ space and weighted by $k^{3}$, generating $k^{3} \chi(k)$ spectra. $k^{3} \chi(k)$ in $k$-space $\left(\AA^{-1}\right)$ was Fourier transformed (FT) to produce the radial structure function (RSF) in $R$-space $(\AA)$. The experimental spectra were fitted with singlescattering theoretical phase-shift and amplitude functions calculated with the $a b$ initio computer code FEFF6 (Deleon et al., 1991) by optimizing the coordination number $(\mathrm{CN})$, interatomic distances $(R)$, and Debye-Waller factors $\left(\sigma^{2}\right)$. The theoretical phase-shift and amplitude functions for a hypothetical cluster of atoms were generated by replacing iron in the crystal structure of scorodite $\left(\mathrm{FeAsO}_{4} \cdot 2 \mathrm{H}_{2} \mathrm{O}\right)$ by titanium.

\section{Results and discussion}

\subsection{Kinetic study}

Results from the kinetic batch experiments are presented in Fig. 1 in order to illustrate the changes in MMA and DMA concentrations versus time. The adsorption rate of MMA and DMA was rapid during the initial stages of reaction and was then followed by slow reactions. A pseudo-second order kinetic model has been applied previously to describe the adsorption of $\mathrm{As}(\mathrm{III})$ and $\mathrm{As}(\mathrm{V})$ on the nanocrystalline $\mathrm{TiO}_{2}$ (Pena et al., 2005). Similar to inorganic As adsorption, organic As also followed pseudo-second order kinetics with the rate equation expressed as $d q / d t=k\left(q_{\mathrm{e}}-q\right)^{2}$, where $q_{\mathrm{e}}$ and $q$ are the amounts of organic As adsorbed per unit weight of $\mathrm{TiO}_{2}$ at equilibrium and at time $t$, respectively $\left(\mathrm{g}-\mathrm{As} / \mathrm{kg}-\mathrm{TiO}_{2}\right)$, and $k$ $\left((\mathrm{g} / \mathrm{kg})^{-1} \mathrm{~min}^{-1}\right)$ is the rate constant. The model parameters inserted in Fig. 1 were obtained by linear regression of the integrated rate equation $\left(R^{2}>0.9995\right)$. The adsorption capacity $q_{\mathrm{e}}$ of MMA (4.61 g-As $/ \mathrm{kg}-\mathrm{TiO}_{2}$ ) was nearly twice that of DMA (2.36 g-As/ $\left.\mathrm{kg}-\mathrm{TiO}_{2}\right)$. The rate constant $k$ was 0.0073 and $0.0091(\mathrm{~g} / \mathrm{kg})^{-1} \mathrm{~min}^{-1}$ for MMA and DMA, respectively. The results indicate that the higher adsorption capacity species (MMA) resulted in a slightly slower adsorption rate. Similar results were obtained with inorganic As adsorption on $\mathrm{TiO}_{2}$ (Pena et al., 2005). The $q_{\mathrm{e}}$ of $\mathrm{As}(\mathrm{V})$ (9.07 g-As $\left./ \mathrm{kg}-\mathrm{TiO}_{2}\right)$ is higher than that of $\mathrm{As}(\mathrm{III})\left(8.47 \mathrm{~g}-\mathrm{As} / \mathrm{kg}-\mathrm{TiO}_{2}\right)$, while $\mathrm{As}(\mathrm{III})\left(k=0.026(\mathrm{~g} / \mathrm{kg})^{-1} \mathrm{~min}^{-1}\right)$ adsorbs faster on $\mathrm{TiO}_{2}$ than $\operatorname{As}(\mathrm{V})\left(k=0.016(\mathrm{~g} / \mathrm{kg})^{-1} \mathrm{~min}^{-1}\right)$ (Pena et al., 2005). The $\mathrm{TiO}_{2}$ adsorption capacity was higher than iron filings, which had

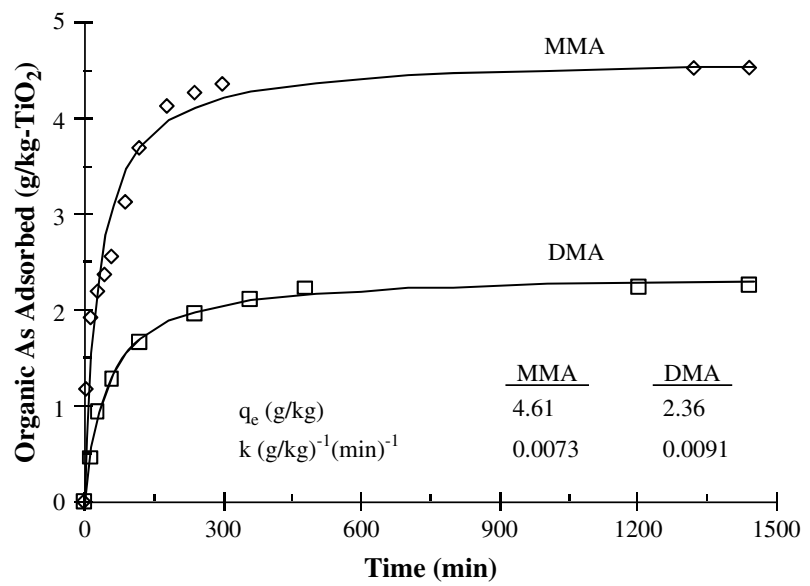

Fig. 1. Adsorption kinetics of $M M A-\mathrm{TiO}_{2}$ and $\mathrm{DMA}-\mathrm{TiO}_{2}$ systems in $0.04 \mathrm{M} \mathrm{NaCl}$ solution. The lines are model calculations. Initial MMA $=\mathrm{DMA}=100 \mu \mathrm{g}-\mathrm{As} \mathrm{L}^{-1}$, $\mathrm{TiO}_{2}=0.02 \mathrm{~g} \mathrm{~L}^{-1}, \mathrm{pH}=6.0$. Inset shows the best-fit parameters using pseudo-second order kinetics. a maximum adsorption capacity for $\mathrm{As}(\mathrm{V}), \mathrm{As}(\mathrm{III}), \mathrm{MMA}$ and DMA at $600,1500,650$, and $20 \mathrm{mg} \mathrm{kg}^{-1}$, respectively (Cheng et al., 2005). In a batch experiment at neutral $\mathrm{pH}$, ferrihydrite exhibit a higher adsorption capacity for As(V), MMA, and DMA (140, 126, and $63 \mathrm{~g}$ $\mathrm{kg}^{-1}$, respectively) than goethite $\left(9.0,9.1\right.$, and $0.5 \mathrm{~g} \mathrm{~kg}^{-1}$ ) (Lafferty and Loeppert, 2005) and $\mathrm{TiO}_{2}$ used in this study.

\subsection{Competitive adsorption}

Competitive adsorption results among four As species on granular $\mathrm{TiO}_{2}$ adsorbent are shown in Fig. 2. The batch experimental results were obtained by adding increasing amounts of $\mathrm{TiO}_{2}$ in contaminated groundwater containing $\mathrm{As}(\mathrm{III}), \mathrm{As}(\mathrm{V}), \mathrm{MMA}$, and DMA at initial concentrations of 368, 305, 122, and $200 \mu \mathrm{g}-\mathrm{As} \mathrm{L}^{-1}$, respectively. Inorganic As and MMA could be removed using $\mathrm{TiO}_{2}$, although the adsorption capacity was adversely affected due to the presence of other As species and competing anions such as silicate in groundwater. However, almost no DMA adsorption was observed even at high $\mathrm{TiO}_{2}$ concentrations up to $10 \mathrm{~g} \mathrm{~L}^{-1}$. This observation was in contrast to the kinetic study result that the DMA adsorption capacity was estimated to be $2.36 \mathrm{~g}-\mathrm{As} / \mathrm{kg}-\mathrm{TiO}_{2}$ (Fig. 1). The results indicated that DMA had a much lower affinity for $\mathrm{TiO}_{2}$ than other arsenic species and its adsorption was hindered by the co-existing anions. DMA forms monodentate surface complexes on $\mathrm{TiO}_{2}$ surface while other As species form more stable bidentate surface complexes (Jing et al., 2005b; Pena et al., 2006).

The CD-MUSIC model has been employed to describe the organic and inorganic As adsorption on $\mathrm{TiO}_{2}$ in previous reports with the constraint of EXAFS microscopic measurements (Jing et al., 2005a,b). The model emphasizes the importance of the surface complex structure and of the charge distribution at the interface, which makes it suitable in competitive adsorption modeling (Hiemstra and van Riemsdijk, 1996, 1999). The surface acid-base reactions, As surface complexation reactions, formation of outersphere complexes with background electrolytes, and their corresponding adsorption constants were listed in Table S1 in the Supplementary material. The CD factor $f$ was determined to be $5 / 9$, $1 / 2,1 / 2$, and $1 / 3$ for $\mathrm{As}(\mathrm{III}), \mathrm{As}(\mathrm{V}), \mathrm{MMA}$, and DMA surface complex, respectively (Supplementary material). The $\mathrm{CD}$ factor indicates the As charge fraction attributed to the surface plane, which is determined by the surface complex structure. The formation constants of the inner-sphere $\mathrm{As}(\mathrm{III}), \mathrm{As}(\mathrm{V}), \mathrm{MMA}$, and DMA complexes were $-1.5,28.8,25.3$, and 9.9 , respectively (Supplementary material), for

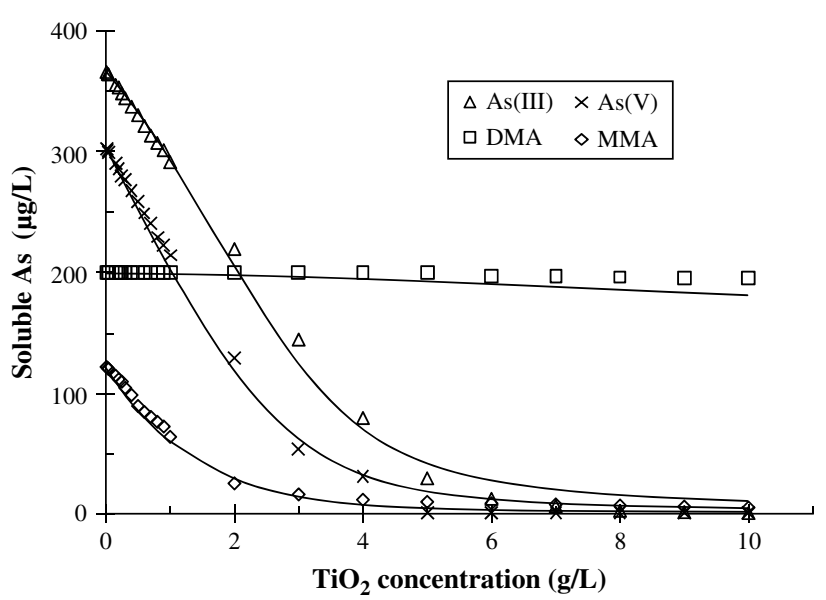

Fig. 2. Competitive adsorption of $\operatorname{As}(\mathrm{III})(\Delta), \operatorname{As}(\mathrm{V})(\times)$, MMA $(\diamond)$, and DMA $(\square)$ in contaminated groundwater on granular $\mathrm{TiO}_{2}$. Initial concentration is $368,305,122$, and $200 \mu \mathrm{g}-\mathrm{As} \mathrm{L}^{-1}$ for $\mathrm{As}(\mathrm{III}), \mathrm{As}(\mathrm{V}), \mathrm{MMA}$, and DMA, respectively. 


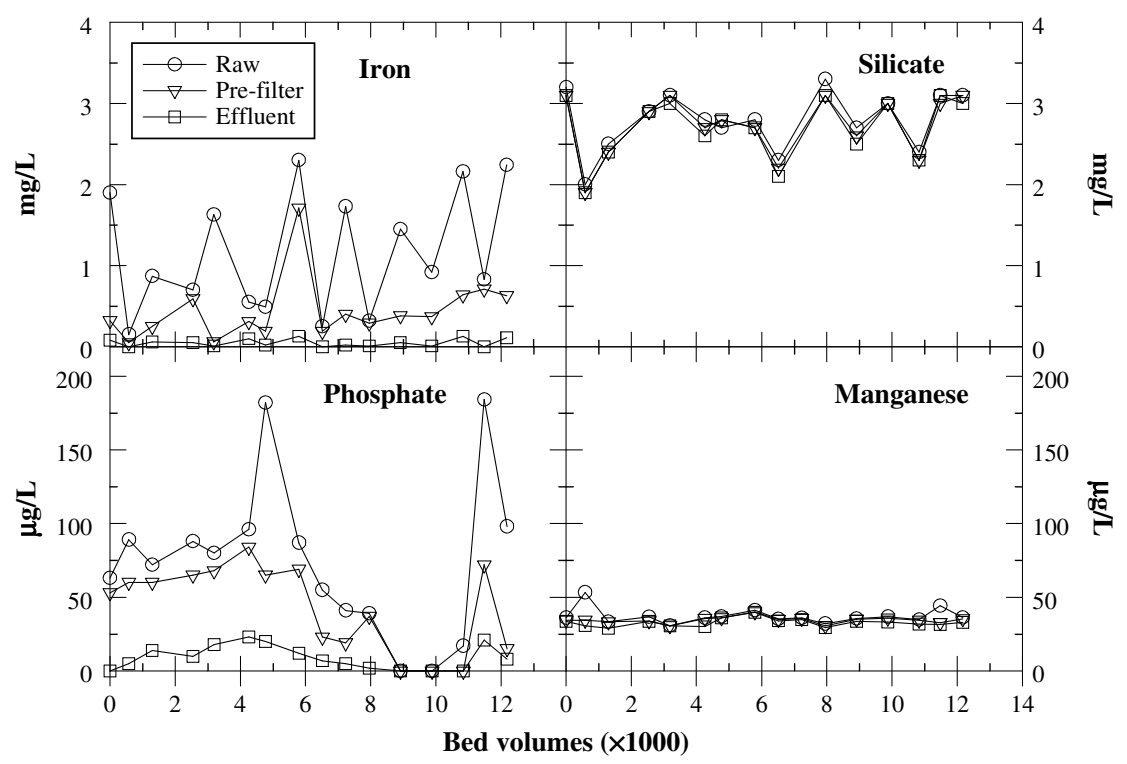

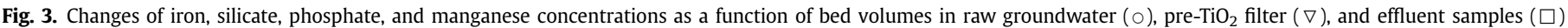
during the filtration experiment. Continuous filtration at a flow rate of $500 \mathrm{~mL} \mathrm{~min}^{-1}$; EBCT $=6 \mathrm{~min}$.

single As species adsorption. The apparent adsorption constants in simulation of competitive adsorption were changed to $0.7,25.5$, 26.0, and 9.9 for $\mathrm{As}(\mathrm{III}), \mathrm{As}(\mathrm{V}), \mathrm{MMA}$, and DMA, respectively, as a result of the competing effect of other As species and anions in groundwater. The change in apparent adsorption constants with and without competition should be ascribed to the changes in micro-structures of adsorbed As species, and the electrostatic potential profile near the surface in the presence and absence of the competing ions. The surface site density was $8.1 \mu \mathrm{mol} \mathrm{g}{ }^{-1}$, which is $0.3 \%$ of the total available sites of the granular $\mathrm{TiO}_{2}$. The CD-MUSIC model could describe the competitive adsorption behavior of these four As species well (Fig. 2). The competitive adsorption of coexisting anions, such as silicate, was not considered in the model.

\subsection{Filtration study}

The physicochemical measurements performed on site indicate that the $\mathrm{pH}$ of the groundwater ranged from 5.6 to 6.3. Dissolved oxygen (DO) was in the range of $1.2-2.8 \mathrm{mg} \mathrm{L}^{-1}$ and temperature was from 15.4 to $18.0^{\circ} \mathrm{C}$.

A field filtration experiment was conducted for approximately 4 months to assess the feasibility of using the granular $\mathrm{TiO}_{2}$ adsorbent for groundwater As remediation. Fig. 3 shows concentrations of iron, silicate, phosphate, and manganese as a function of bed volumes in raw groundwater, pre- $\mathrm{TiO}_{2}$ filter (i.e., after sediment filter), and effluent samples during the filtration experiment. The average total concentration for iron, silicate, phosphate, and

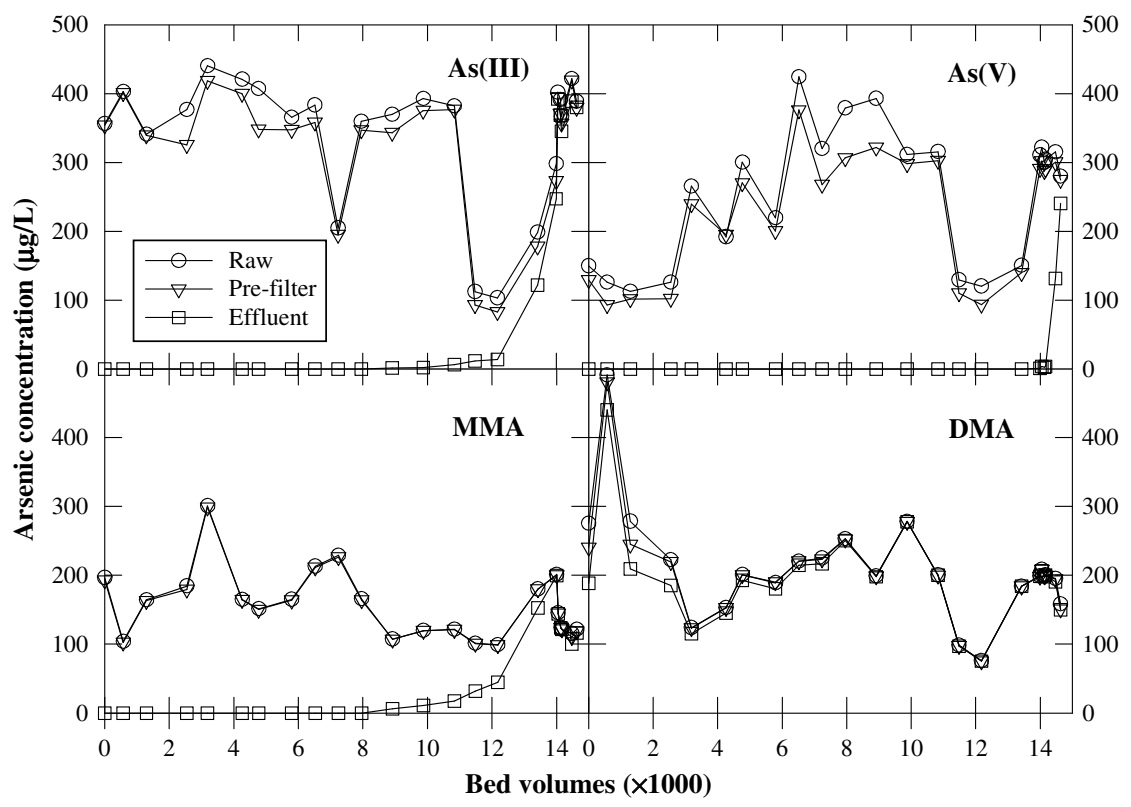

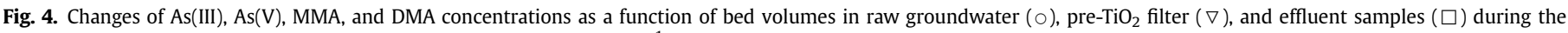
filtration experiment. Continuous filtration at a flow rate of $500 \mathrm{~mL} \mathrm{~min}^{-1}$; EBCT $=6 \mathrm{~min}$. 
manganese in groundwater was 1.2, 2.6, 0.07, and $0.04 \mathrm{mg} \mathrm{L}^{-1}$, respectively. The difference of iron concentrations in raw and pre$\mathrm{TiO}_{2}$ filter samples indicates the existence of particulate iron species in raw water (Fig. 3). The iron particles may associate with phosphate in raw water, as suggested by the phosphate concentration difference in raw and pre- $\mathrm{TiO}_{2}$ filter samples. The soluble iron and phosphate was further removed in the $\mathrm{TiO}_{2}$ column as evidenced by the low effluent concentrations (Fig. 3). In contrast, almost no silicate and manganese were removed by the sediment and $\mathrm{TiO}_{2}$ filter, suggesting the $\mathrm{TiO}_{2}$ column was not effective in soluble silicate and manganese removal.

The concentrations of $\mathrm{As}(\mathrm{III}), \mathrm{As}(\mathrm{V}), \mathrm{MMA}$, and DMA in groundwater, pre- $\mathrm{TiO}_{2}$ filter, and effluent samples were monitored as a function of bed volumes and are shown in Fig. 4. The MMA and DMA concentrations in raw and pre-filter samples were almost identical, suggesting no association of organic As with particulate iron species. Over $90 \%$ of the inorganic As species were not associated with iron particles and passed through the sediment filter. Approximately 11000,14000 , and 9900 bed volumes of water had been treated by the $\mathrm{TiO}_{2}$ filter at breakthrough when the $\mathrm{As}(\mathrm{III})$, $\mathrm{As}(\mathrm{V})$, and MMA concentration in the effluent increased to $10 \mu \mathrm{g} \mathrm{L}^{-1}$. A mass balance calculation based on the amount of water treated and the pre- $\mathrm{TiO}_{2}$ filter and effluent As concentrations indicate that the $\mathrm{As}(\mathrm{III}), \mathrm{As}(\mathrm{V})$, MMA, and DMA content in spent $\mathrm{TiO}_{2}$ was $3.93,4.05,2.41$, and $0.18 \mathrm{mg} \mathrm{g}^{-1}$, respectively. The adsorption capacity for As species was nearly half of that obtained with kinetic study (Fig. 1). The results show that a small amount of DMA was removed at the beginning of the filtration experiment, and then no significant DMA removal was observed. Photocatalytical degradation of methylated As species using $\mathrm{TiO}_{2}(\mathrm{Xu}$ et al., 2008) could be used as a pretreatment to improve the As removal in groundwater. The adsorption capacity for $\mathrm{As}(\mathrm{V})$ (4.05 $\mathrm{mg} \mathrm{g}^{-1}$ ) obtained in this study was higher than a previous report (1.7 $\mathrm{mg} \mathrm{g}^{-1}$ ) using the same adsorbent for groundwater As(V) removal (Bang et al., 2005). The higher pH values (7.7-8.2) and shorter empty bed contact time (3 min) in previous study (Bang et al., 2005) may attribute to the decreased $\mathrm{As}(\mathrm{V})$ adsorption capacity.

The breakthrough curves were developed from the column experiment by plotting the ratio of $C / C_{0}$ for each As species as a function of bed volumes (Fig. 5). To understand the reactions taking place in the column, reactive transport modeling was carried out with PHREEQC 2.0 including pseudo-second order kinetics, CDMUSIC, and 1D advective transport reactions (Parkhurst and Appelo, 1999). The model results shown in Fig. 5 are in general

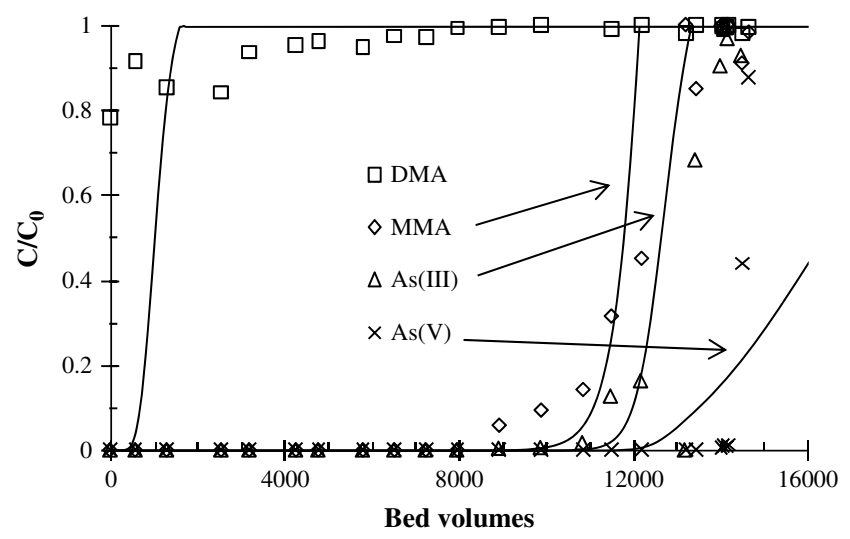

Fig. 5. Observed and calculated breakthrough curves for $\operatorname{As}(\mathrm{III})(\Delta), \operatorname{As}(\mathrm{V})(\times), \operatorname{MMA}$ $(\diamond)$, and DMA $(\square)$ as a function of bed volumes during the filtration experiment. Flow rate $=500 \mathrm{~mL} \min ^{-1} ; \mathrm{EBCT}=6 \mathrm{~min}$. agreement with the observed breakthrough curves, with the model predicting a somewhat gentler slope for $\mathrm{As}(\mathrm{V})$ and sharper slope for MMA and As(III). The difference between the model prediction and the experimental observation may be attributed to the complexity of the groundwater and the simplicity of the model. The surface complexation constants in CD-MUSIC for As(III), As(V), and MMA were adjusted from 0.7, 25.5, 26.0, and 9.9 obtained using batch competitive tests to $0.4,25.5,24.7$, and 9.9 in the column experiment, respectively.
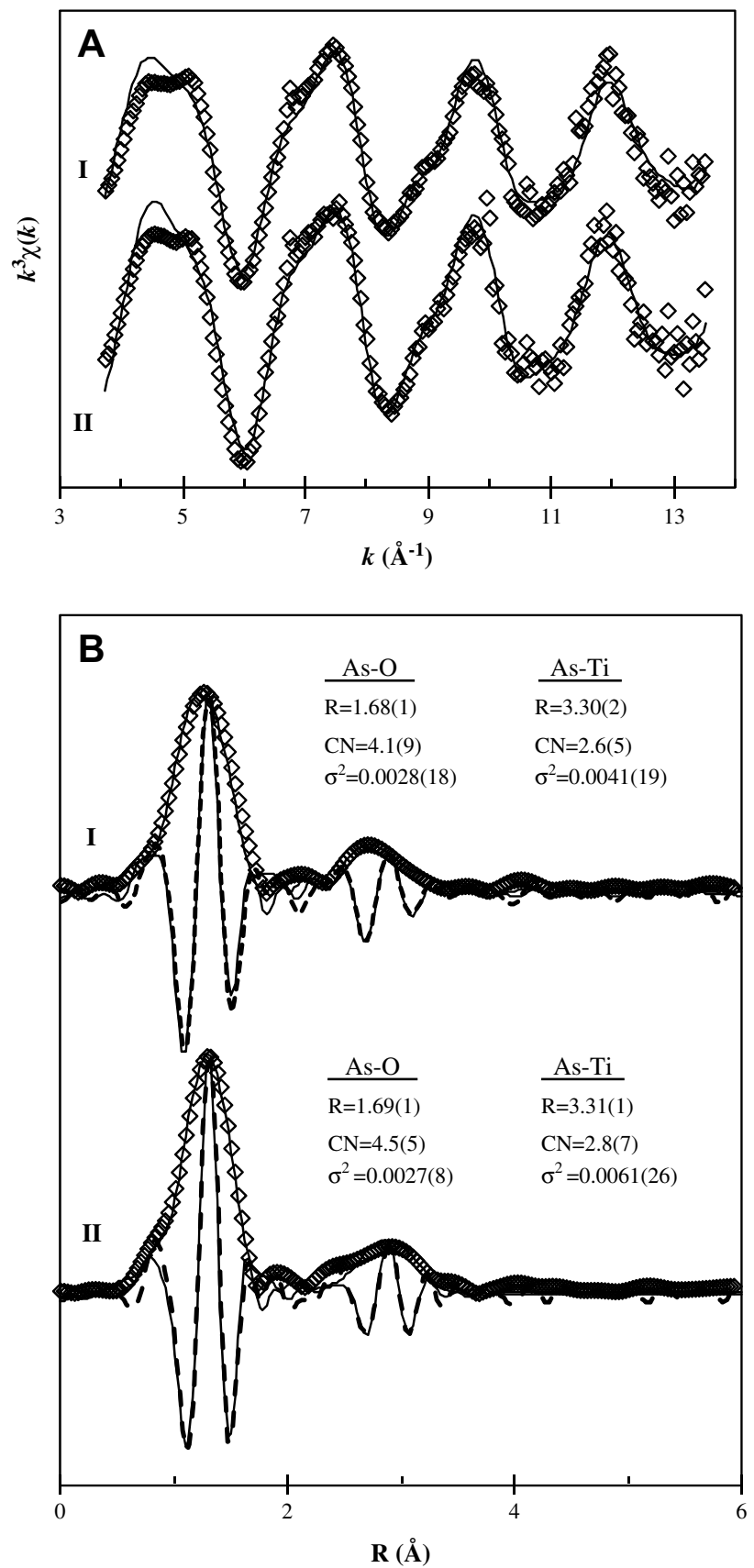

Fig. 6. Normalized $k^{3}$-weighted observed (diamond line) and model calculated (solid line) As K-edge EXAFS (A), and the corresponding magnitude (diamond line) and real parts (dashed line) of Fourier transform ( $B, x$-axis not corrected for phase shifts) spectra for samples at $5 \mathrm{~cm}$ below the surface (I) and at $5 \mathrm{~cm}$ above the bottom (II) in the spent $\mathrm{TiO}_{2}$ column. Numerical fit results (inset) are true interatomic distances $(R)$ corrected for backscatterer phase shifts; $\mathrm{CN}$ is the average coordination number of backscatterers, and $\sigma^{2}$ is the Debye-Waller disorder parameter. 


\subsection{EXAFS study}

EXAFS spectroscopy was employed to determine the arsenic local coordination environment for spent adsorbent at $5 \mathrm{~cm}$ depth below the surface and at $5 \mathrm{~cm}$ above the bottom in the $\mathrm{TiO}_{2}$ column. The $k^{3}$-weighted As K-edge EXAFS spectra are shown in Fig. 6(A), and the corresponding radial structure functions (RSF) are shown in Fig. 6(B) as magnitude and real part of the Fourier transformation (FT) versus radial distance. The optimal parameters inserted in Fig. 6(B) were obtained by fitting the theoretical curves to the experimental spectra.

The EXAFS results show that the first and strongest peak in the FT curve was contributed by 4.1 and 4.5 oxygen atoms at an average distance of 1.68 and $1.69 \AA$ for the top and bottom sample, respectively. The As- $O$ interatomic distance suggested the adsorbed $\mathrm{As}$ was in $\mathrm{As}(\mathrm{V})$ form and the $\mathrm{AsO}_{4}$ tetrahedral geometry remained relatively rigid on the $\mathrm{TiO}_{2}$ surface. The second shell can be fitted with 2.6 and $2.8 \mathrm{Ti}$ atoms at a distance of 3.30 and $3.31 \AA$ for the top and bottom sample, respectively. The distances and coordination numbers $(\mathrm{CN})$ of As-O and As-Ti are in good agreement with previously published data (Jing et al., 2005a; Pena et al., 2006), indicating the formation of a bidentate binuclear $\mathrm{As}(\mathrm{V})$ surface complex on $\mathrm{TiO}_{2}$ adsorbent.

The surface As speciation analysis using EXAFS indicated the oxidation of adsorbed $\mathrm{As}(\mathrm{III})$ to $\mathrm{As}(\mathrm{V})$ in the $\mathrm{TiO}_{2}$ column. Thermodynamically, As(III) can be oxidized to $\mathrm{As}(\mathrm{V})$ by dissolved oxygen in water, although the oxidation rate is slow (Meng et al., 2002). In this study, dissolved oxygen in groundwater $\left(1.2-2.8 \mathrm{mg} \mathrm{L}^{-1}\right)$ could oxidize adsorbed $\mathrm{As}$ (III) in the presence of $\mathrm{TiO}_{2}$ during the 4-month filtration process. Foster et al. (1998) reported a similar finding that $19 \%$ of $\mathrm{As}(\mathrm{III})$ was oxidized to $\mathrm{As}(\mathrm{V})$ by anatase in darkness within $14 \mathrm{~h}$ contact time. The oxidation reaction is a benefit to As remediation because $\mathrm{As}(\mathrm{V})$ has a higher affinity than $\mathrm{As}(\mathrm{III})$. The unidentifiable MMA species on spent $\mathrm{TiO}_{2}$ may be ascribed to the ambiguity between oxygen and carbon atoms in the As first shell analysis, and to its low abundance compared to the inorganic As species.

\section{Conclusions}

Adsorption of As species on $\mathrm{TiO}_{2}$ followed pseudo-second order rate kinetics. Almost no DMA adsorption was observed in the presence of other As species and competing ions in groundwater. The CD-MUSIC model with the triple plane option was able to describe the competitive As adsorption behaviors. The field filtration results demonstrated that 11000,14000 , and 9900 bed volumes of water had been treated before the $\mathrm{As}(\mathrm{III}), \mathrm{As}(\mathrm{V})$, and MMA concentration in the effluent increased to $10 \mu \mathrm{g} \mathrm{L}^{-1}$. A mass balance calculation showed that the $\mathrm{As}(\mathrm{III}), \mathrm{As}(\mathrm{V}), \mathrm{MMA}$, and DMA content in spent $\mathrm{TiO}_{2}$ was 3.93, 4.05, 2.41, and $0.18 \mathrm{mg} \mathrm{g}^{-1}$, respectively. Adsorbed $\mathrm{As}(\mathrm{III})$ in the $\mathrm{TiO}_{2}$ filter was oxidized to $\mathrm{As}(\mathrm{V})$ in the presence of dissolved oxygen.

\section{Acknowledgements}

We acknowledge the staff on beamline X18B at the National Synchrotron Light Source (NSLS) for their assistance with XAS data collection. C.J. would like to thank the partial support by the National Natural Science Foundation of China (20847002 and 20621703).

\section{Appendix A. Supplementary material}

Supplementary material showing the surface parameters and surface complexation reactions used in the CD-MUSIC modeling associated with this article is available online at doi:10.1016/j. envpol.2009.03.011.

\section{References}

Bang, S., Patel, M., Lippincott, L., Meng, X., 2005. Removal of arsenic from groundwater by granular titanium dioxide adsorbent. Chemosphere 60 (3), 389-397.

Brooks, W.E., 2006. Minerals Yearbook - Arsenic. USGS. On-line document available at: http://minerals.usgs.gov/minerals/pubs/commodity/arsenic/.

Cheng, Z.Q., van Geen, A., Louis, R., Nikolaidis, N., Bailey, R., 2005. Removal of methylated arsenic in groundwater with iron filings. Environmental Science \& Technology 39 (19), 7662-7666.

Clesceri, L.S., Greenberg, A.E., Trussell, R.R., Franson, M.A., 1999. Standard Methods for the Examination of Water and Wastewater. Method 4500-P E, twentieth ed. American Public Health Association, Washington, DC.

Cullen, W.R., Reimer, K.J., 1989. Arsenic speciation in the environment. Chemical Reviews 89 (4), 713-764.

Deleon, J.M., Rehr, J.J., Zabinsky, S.I., Albers, R.C., 1991. Ab initio curved-wave X-ray absorption fine structure. Physical Review B 44 (9), 4146-4156.

Edwards, M., 1994. Chemistry of arsenic removal during coagulation and Fe-Mn oxidation. Journal of American Water Works Association 86 (9), 64-78.

Feng, M., Schrlau, J.E., Snyder, R., Snyder, G.H., Chen, M., Cisar, J.L., Cai, Y., 2005. Arsenic transport and transformation associated with MSMA application on a golf course green. Journal of Agricultural and Food Chemistry 53 (9), 3556-3562.

Foster, A.L., Brown, G.E., Parks, G.A., 1998. X-ray absorption fine-structure spectroscopy study of photocatalyzed, heterogeneous As(III) oxidation on kaolin and anatase. Environmental Science \& Technology 32 (10), 1444-1452.

Hiemstra, T., van Riemsdijk, W.H., 1996. A surface structural approach to ion adsorption: the charge distribution (CD) model. Journal of Colloid and Interface Science 179 (2), 488-508.

Hiemstra, T., van Riemsdijk, W.H., 1999. Surface structural ion adsorption modeling of competitive binding of oxyanions by metal (hydr)oxides. Journal of Colloid and Interface Science 210 (1), 182-193.

Jing, C., Liu, S., Patel, M., Meng, X., 2005a. Arsenic leachability in water treatment adsorbents. Environmental Science \& Technology 39 (14), 5481-5487.

Jing, C., Meng, X., Liu, S., Baidas, S., Patraju, R., Christodoulatos, C., Korfiatis, G.P., 2005b. Surface complexation of organic arsenic on nanocrystalline titanium oxide. Journal of Colloid and Interface Science 290 (1), 14-21.

Lafferty, B.J., Loeppert, R.H., 2005. Methyl arsenic adsorption and desorption behavior on iron oxides. Environmental Science \& Technology 39 (7), 2120-2127.

Liu, S., Jing, C., Meng, X., 2008. Arsenic re-mobilization in water treatment adsorbents under reducing conditions: part II. XAS and modeling study. Science of the Total Environment 392 (1), 137-144

Meng, X., Dadachov, M., Korfiatis, G.P., Christodoulatos, C., 2005. Method of Preparing a Surface-activated Titanium Oxide Product and of Using the Same in Water Treatment Processes. US Patent: 6919029.

Meng, X., Jing, C., Korfiatis, G.P., 2002. A review of redox transformation of arsenic in aquatic environments. In: Cai, Y., Braids, O.C. (Eds.), Biogeochemistry of Environmentally Important Element. American Chemical Society, Washington, DC, USA, pp. 70-83.

Mohan, D., Pittman Jr., C.U., 2007. Arsenic removal from water/wastewater using adsorbents-A critical review. Journal of Hazardous Materials 142, 1-53.

Parkhurst, D.L., Appelo, C.A.J., 1999. User's Guide to PHREEQC (Version 2) a Computer Program for Speciation, Reaction-Path, 1D-Transport, and Inverse Geochemical Calculations. U.S. Geological Survey Water Resources Investigations Report 99-4259. U.S. Geological Survey, Denver, USA

Pena, M., Meng, X., Korfiatis, G.P., Jing, C., 2006. Adsorption mechanism of arsenic on nanocrystalline titanium dioxide. Environmental Science \& Technology 40 (4), 1257-1262.

Pena, M., Korfiatis, G.P., Patel, M., Lippincott, L., Meng, X., 2005. Adsorption of As(V) and $\mathrm{As}(\mathrm{III})$ by nanocrystalline titanium dioxide. Water Research 39 (11), 23272337.

Ravel, B., Newville, M., 2005. ATHENA, ARTEMIS, HEPHAESTUS: data analysis for Xray absorption spectroscopy using IFEFFIT. Journal of Synchrotron Radiation 12, 537-541.

Smedley, P.L., Kinniburgh, D.G., 2002. A review of the source, behaviour and distribution of arsenic in natural waters. Applied Geochemistry 17 (5), 517-568.

Thirunavukkarasu, O.S., Viraraghavan, T., Subramanian, K.S., Tanjore, S., 2002. Organic arsenic removal from drinking water. Urban Water 4, 415-421.

US Army Corps., 1994. Remediation of Vineland Chemical Company Site Superfund Project. Design Analysis Report. Malcolm Pirnie, White Plains, NY, USA.

US Environmental Protection Agency, 2003. Arsenic Treatment Technology Evaluation Handbook for Small Systems. EPA-816-R-03-014. US Environmental Protection Agency, Washington, DC, USA.

US Environmental Protection Agency, 2008. Assessing Arsenic Removal by Metal (Hydr)oxide Adsorptive Media Using Rapid Small Scale Column Tests. EPA-600R-08-051. US Environmental Protection Agency, Washington, DC, USA

US Geological Survey, 2005. Arsenic statistics. In: Kelly, T.D., Matos, G.R. (Eds.), Historical Statistics for Mineral and Material Commodities in the United States: U.S. Geological Survey Data Series 140 Available online at: http://pubs.usgs.gov/ ds/2005/140/.

Xu, T.L., Cai, Y., O'Shea, K.E., 2007. Adsorption and photocatalyzed oxidation of methylated arsenic species in $\mathrm{TiO}_{2}$ suspensions. Environmental Science \& Technology 41 (15), 5471-5477.

Xu, Z., Jing, C., Li, F., Meng, X., 2008. Mechanisms of photocatalytical degradation of monomethylarsonic and dimethylarsinic acids using nanocrystalline titanium dioxide. Environmental Science \& Technology 42 (7), 2349-2354. 